\title{
PENGARUH PENGURANGAN KADAR AIR DAN PENGGUNAAN BAHAN PENGIKAT KADAR AIR DALAM PEMBUATAN CAKE BENGKUANG
}

\section{Effect of Water Content Reduction and Using of Binder Material In Making of Yam Cake}

\author{
Wilsa Hermianti*, Yulia Helmi Diza, Firdausni, dan Tri Wahyuningsih \\ Balai Riset dan Standardisasi Industri Padang \\ JI. Raya LIK No. 23 Ulu Gadut Padang \\ *e-mail: wilsadjaswir@gmail.com
}

\begin{abstract}
ABSTRAK
Bengkuang mengandung kadar air yang tinggi berkisar $86-90 \%$ sehingga jika diolah untuk menjadi produk berupa cake akan memberikan kadar air yang juga tinggi dan menyebabkan produk menjadi tidak tahan lama. Dengan sifat alami bengkuang tersebut maka dilakukan upaya pemanfaatannya menjadi cake bengkuang dalam rangka pengembangan olahan dari bengkuang, peningkatan nilai tambah, dan diversifikasi olahan pangan berbasis bahan baku lokal yang cukup potensi di kota Padang. Bengkuang dapat dimanfaatkan dengan mengolahnya menjadi pangan semi basah berupa cake bengkuang dengan jumlah bengkuang yang dominan yakni sampai $50 \%$ dari adonan cake namun hanya mempunyai ketahanan simpan selama 3 hari. Guna meningkatkan masa simpannya dilakukan penelitian pengurangan kadar air bahan baku bengkuang dan penggunaan bahan pengikat dalam pembuatan cake bengkuang. Perlakuan pengurangan kadar air bengkuang dilakukan dengan menggunakan juicer dan dipress. Sebagai pembanding (kontrol) dilakukan tanpa pengurangan kadar air. Penggunaan bahan pengikat kadar air bengkuang adalah dengan penambahan kelapa, tepung maizena, dan tepung beras. Cake bengkuang menggunakan formula bahan pengikat kandungan air bengkuang dengan tepung maizena serta pengurangan kadar air bahan baku bengkuang dengan dipress memberikan hasil yang optimal dengan nilai organoleptik yang disukai panelis, kadar air 28,50\%, karbohidrat $56,31 \%$, protein $6,13 \%$, lemak $10,23 \%$, energi $341,86 \mathrm{kkal} / 100 \mathrm{~g}$, serat pangan $5,98 \%$, kalsium $27,77 \mathrm{mg} / 100 \mathrm{~g}$, dan inulin $5,92 \%$, daya simpan selama 5 hari pada suhu kamar dan 4 minggu pada suhu kulkas.
\end{abstract}

Kata kunci: Bengkuang, kadar air, cake bengkuang, pengikat, nilai tambah, umur simpan

\begin{abstract}
Yam contains a high water content ranging from $86-90 \%$ therefore when be processed to be a product such as cake will also result a high water content and cause the product is not durable. By the nature characteristics of the yam was then made utilization efforts became yam cake in order to develop yam processing, increase value added, and diversify food processing based on raw materials of local potential in Padang City. Yam can be used by processing them into a semi wet food such as cake with a dominant amount of yam up to $50 \%$ of the cake batter, but only had a shelf life for 3 days. To increase the shelf-life study was carried out water content reduction of raw materials and using of a binder in the making of yam cake. The treatment of water content reduction of yam was done using juicer and pressing. A comparison as a control was performed without reduction of water content. The use of water content binder was conducted with the addition of coconut, cornstarch, and rice flour. Yam cake formulas using binder of water content with cornstarch and reduction the water content of raw material by pressing showed optimal results with a preferred value of organoleptic panelist, the water content $28.50 \%$, carbohydrate $56.31 \%$, protein $6.13 \%$, fat $10.23 \%$, energy $341.86 \mathrm{kcal} / 100 \mathrm{~g}$, dietary fiber $5.98 \%$, calcium $27.77 \mathrm{mg} / 100 \mathrm{~g}$, and $5.92 \%$ inulin, storability for 5 days at room temperature and 4 weeks at refrigerator temperature.
\end{abstract}

Keywords: yam, water content, yam cake, binders, value added, shelf life 


\section{PENDAHULUAN}

Bengkuang (Pachyrhizus erosus) dikenal dari umbi (cormus) berwarna putih. Bengkuang potensial di kota Padang sehingga Padang dikenal juga sebagai kota bengkuang dan dijadikan maskot kota Padang. Pemanfaatan bengkuang di kota Padang selama ini belum mendapat perhatian yang cukup besar oleh pemerintah maupun masyarakat (Kurniawan, 2013). Bengkuang di kota Padang tidak mengenal musiman dan selalu ada setiap hari (Pratiwi, 2015). Menurut data Statistika tahun 2013 terdapat 119 ha luas panen bengkuang dengan produksi 3.101,10 ton. Selama ini bengkuang segar sering dijadikan sebagai buah tangan atau oleh-oleh dari kota Padang. Pengolahan bengkuang menjadi produk pangan belum banyak ditemukan, biasanya hanya sebagai komponen rujak, buah air, manisan, asinan, dan bahan baku bedak dingin.

Umbi bengkuang berbentuk bulat atau membulat seperti gasing dengan kulit umbi yang tipis, berwarna kuning pucat dan bagian dalamnya berwarna putih dengan cairan segar agak manis. Bengkuang merupakan buah yang kaya akan berbagai zat gizi yang penting untuk kesehatan terutama vitamin dan mineral. Secara kimia bengkuang banyak mengandung vitamin $\mathrm{C}$, kalsium, fosfor, dan serat yang sangat dibutuhkan tubuh. Bengkuang sebagai sumber serat pangan yang baik untuk pencernaan dan dapat dijadikan sebagai alternatif penyusun makanan fungsional (Harmayanti, 2011). Bengkuang mengandung kadar air yang cukup tinggi sekitar $86-90 \%$ sehingga dapat menyegarkan tubuh setelah mengkonsumsinya dan menambah cairan tubuh, bengkuang juga memiliki efek pendingin. Disamping itu bengkuang mengandung oligosakarida (inulin) yang berguna bagi penderita diabetes.

Bengkuang mudah mengalami kerusakan jika disimpan dalam keadaan segar dan untuk meningkatkan umur simpannya perlu alternatif pengolahan menjadi produk baru yang mempunyai nilai ekonomis (Syarif dan Waryono, 2014). Disisi lain kebutuhan bahan pangan semakin meningkat seiring dengan bertambahnya populasi manusia. Bahan dasar dari produk pangan sangat terbatas sehingga dibutuhkan diversifikasi yang baik dan tepat untuk menghasilkan produk pangan yang lebih bervariasi. Salah satu bentuknya adalah dalam pembuatan cake (Susilo dan Imelda, 2007). Bengkuang dapat digunakan sebagai alternatif dalam pengembangan diversifikasi pangan (Dewi et al., 2012).

Cake merupakan salah satu jenis makanan yang cukup popular dan biasanya dijadikan sebagai makanan hidangan di sela-sela minum teh dan kopi. Pada umumnya cake dibuat dari tepung terigu. Sampai saat ini kebutuhan akan tepung terigu masih impor. Untuk mengurangi ketergantungan tersebut diperlukan bahan pengganti yang mengandung pati dalam pembuatan cake (Haryadi, 1993).

Cake atau bolu adalah produk pangan semi basah dengan bahan dasar tepung, gula, dan telur. Pada umumnya cake dibuat dari tepung gandum atau tepung terigu. Cake umumnya dimatangkan dengan cara dipanggang dalam oven, walaupun ada juga yang dikukus. Penambahan lemak nabati atau hewani dalam bentuk mentega, margarin, santan ke dalam adonan membuat tekstur kue menjadi lebih lembut (Braker, 2003).

Penelitian pemanfaatan bengkuang menjadi pangan semi basah berupa cake bengkuang telah dilakukan Hermianti et al., (2013) menggunakan bengkuang dalam jumlah yang dominan yakni sampai 50\% dari total adonan, namun mempunyai ketahanan simpan hanya selama 3 hari. Berdasarkan hal tersebut maka dilakukan penelitian dengan pengurangan kadar air bahan baku bengkuang dan penggunaan bahan pengikat kandungan air pada bengkuang yakni dengan kelapa, tepung maizena atau tepung beras guna memperpanjang masa simpan cake bengkuang yang dihasilkan. Cake bengkuang yang dihasilkan diuji secara organoleptik, dianalisis secara kimia serta diamati daya simpannya secara organoleptik. Penelitian ini bertujuan untuk menyediakan informasi teknologi proses peningkatan mutu cake bengkuang yang dapat diaplikasikan oleh industri pengolahan bengkuang sebagai upaya 
diversifikasi produk olahan bengkuang yang disukai secara organoleptik, namun tetap mempunyai kandungan gizi yang baik.

\section{METODOLOGI PENELITIAN}

Bahan yang diperlukan dalam penelitian ini adalah bengkuang, tepung terigu, gula pasir, telur, mentega, pengembang kue, kelapa parut, tepung maizena, tepung beras, bahan kue untuk topping, bahan kemasan dan bahan kimia untuk pengujian $(\mathrm{HCl}, \mathrm{NaOH}, \mathrm{KI}$, glukosa, aquades, methylen blue, Fehling $A$, Fehling $B$, kalium, sodium tartrat, $\mathrm{H}_{2} \mathrm{SO}_{4}$, indikator phenolphtalein, asam boraks, $\mathrm{KMNO}_{4}$, dan bahan kimia lainnya). Peralatan yang digunakan adalah mixer, juicer, press buah, oven, dan alat-alat untuk pengujian yakni neraca, oven, destilator kjedhal, furnace, dan alat titrasi.

$$
\text { Penelitian dilakukan dengan }
$$

perlakuan pengurangan kadar air bahan baku bengkuang yakni dengan diblender (tanpa pengurangan kadar air), pengurangan kadar air dengan juicer dan pengurangan kadar air dengan press buah yang dikombinasikan dengan perlakuan penggunaan bahan pengikat kadar air bengkuang yakni dengan penambahan kelapa, tepung maizena, dan tepung beras dengan rancangan penelitian seperti berikut ini.

A: Perlakuan penggunaan bahan pengikat kadar air bengkuang: penambahan kelapa (A1), penambahan tepung maizena (A2), penambahan tepung beras (A3).

$\mathrm{B}$ : Perlakuan pengurangan kadar air: tanpa pengurangan kadar air /kontrol (B1), pengurangan kadar air dengan juicer (B2) dan pengurangan dengan press (B3).

\section{Proses Pembuatan Cake Bengkuang}

Pembuatan cake bengkuang yang dilakukan adalah seperti pada Gambar 1.

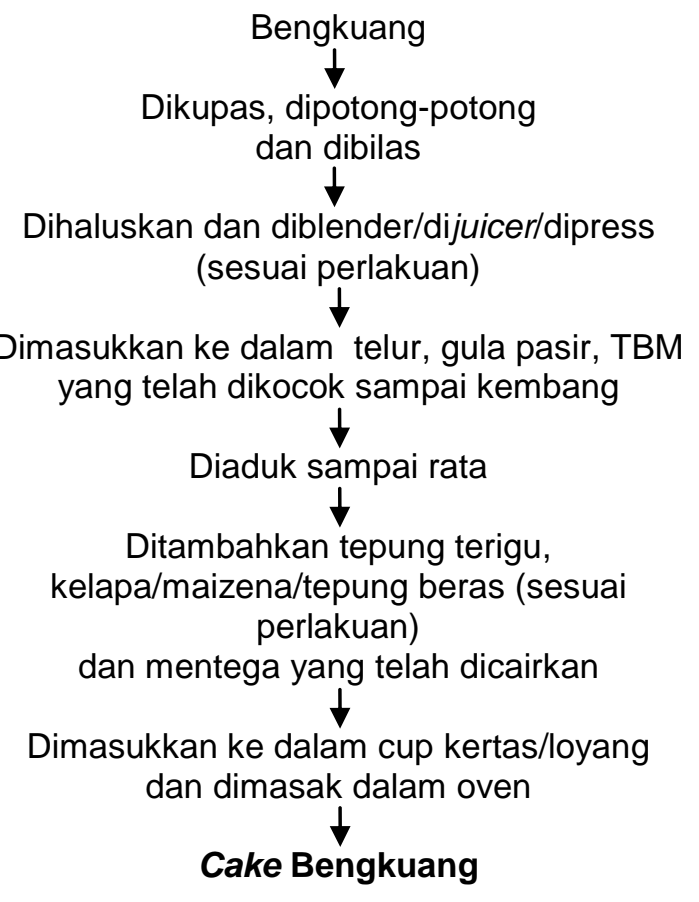

Gambar 1. Diagram alir pembuatan cake bengkuang

\section{Analisis}

Analisis yang dilakukan meliputi analisis kimia bahan baku bengkuang segar yakni kadar air, kadar gula, kadar serat pangan, vitamin B1, kalsium, dan inulin. Analisis kimia produk cake bengkuang yakni kadar air, karbohidrat, protein, lemak, dan energi. Perlakuan yang memberikan hasil optimal secara organoleptik ditambahkan analisis kimia yakni kadar serat pangan, vitamin B1, kalsium, dan inulin. Uji organoleptik (warna, aroma, rasa, dan tekstur) cake bengkuang dilakukan oleh panelis menurut tingkat kesukaan atau penerimaan panelis terhadap cake bengkuang hasil perlakuan pada penelitian ini. Untuk mendapatkan formula yang lebih disukai dengan tipe uji hedonik menggunakan skala numerik sebagai berikut: $5=$ sangat suka, $4=$ suka, 3 = cukup suka, 2 = kurang suka, 1 = tidak suka. Pengamatan daya simpan cake bengkuang dilakukan secara visual dan organoleptik. 
HASIL DAN PEMBAHASAN

Bahan Baku Bengkuang

Permasalahan kadar air yang cukup tinggi pada cake bengkuang yang disebabkan karena tingginya kadar air pada bengkuang segar maka dilakukan penelitian perlakuan penambahan bahan pengikat kadar air dengan kelapa, tepung maizena atau tepung beras serta perlakuan pengurangan kadar air bengkuang yang digunakan dengan cara dijuicer serta dengan cara dipress dan dibandingkan dengan bengkuang yang dihancurkan dengan blender. Pada penelitian ini juga dilakukan pengamatan rendemen. Rendemen daging buah bengkuang dari bengkuang segar diblender yang diperoleh $93,75 \%$, dijuicer $34,30 \%$ sedangkan yang dipress $31 \%$.

Serat bengkuang yang diperoleh dengan dipress semakin berkurang dan juice bengkuang yang diperoleh semakin bertambah dibanding perlakuan lain. Serat bengkuang inilah yang kemudian digunakan untuk membuat cake bengkuang. Diharapkan dengan berkurangnya kadar air bengkuang pada bahan baku bengkuang yang digunakan dapat meningkatkan daya simpan produk cake bengkuang tetapi tetap menunjukkan kekhasan dan masih mempunyai kandungan gizi yang baik untuk kesehatan serta memberikan penilaian organoleptik yang disukai panelis.

Hasil analisis kimia bengkuang dengan perlakuan pengurangan kadar air seperti terlihat pada Tabel 1.

Tabel 1.Hasil analisis kimia bengkuang

\begin{tabular}{lcc}
\hline $\begin{array}{l}\text { Perlakuan } \\
\text { Pengurangan } \\
\text { kadar air }\end{array}$ & $\begin{array}{c}\text { Kadar Air } \\
(\%)\end{array}$ & $\begin{array}{c}\text { Kadar } \\
\text { Gula (\%) }\end{array}$ \\
\hline $\begin{array}{l}\text { Bengkuang yang } \\
\text { diblender }\end{array}$ & 82,89 & 3,46 \\
\hline $\begin{array}{l}\text { Bengkuang yang } \\
\text { dijuicer }\end{array}$ & 80,49 & 4,00 \\
\hline $\begin{array}{l}\text { Bengkuang yang } \\
\text { dipress }\end{array}$ & 79,47 & 4,58 \\
\hline
\end{tabular}

Dari data tersebut terlihat bahwa terjadi pengurangan kadar air dimana bengkuang yang diblender mengandung kadar air yang cukup tinggi sehingga menghasilkan cake yang agak basah dengan kadar air cake bengkuang berkisar $45,86 \%$ - 49,34\%. Hal ini menyebabkan cake bengkuang tersebut tidak tahan lama, yakni hanya tahan selama 3 hari dengan tekstur yang agak basah. Tekstur merupakan suatu komponen yang turut menentukan kualitas dari suatu makanan dan dapat dirasakan melalui sentuhan kulit atau pencicipan (Setyaningsih et al., 2010).

Perlakuan pengurangan kadar air bengkuang dengan cara dijuicer menunjukkan kadar air yang lebih rendah dibanding dengan diblender sedangkan pengurangan kadar air dengan cara dipress memberikan kadar air yang terendah diantara perlakuan tersebut. Kadar gula dari bahan baku yang digunakan berbanding terbalik dengan kadar air akibat perlakuan cara pengurangan kadar air. Semakin rendah kadar air menghasilkan kadar gula yang lebih tinggi. Hal ini menunjukkan bahwa serat bengkuang juga mengandung gula yang tinggi sekalipun kadar airnya berkurang dan sebagian gula ikut terbawa bersama air yang dikurangi berupa juice bengkuang yang juga berasa manis. Kadar air pada bahan baku bengkuang yang diblender dengan yang dipress mengalami pengurangan sebesar 3,42\% dan kadar gula mengalami peningkatan sebesar $1,12 \%$.

\section{Cake Bengkuang}

Hasil perlakuan cara pengurangan kadar air pada bengkuang dikombinasikan dengan perlakuan formula yang diharapkan dapat mengikat kadar air yang tinggi tersebut yakni dengan penambahan kelapa parut, tepung maizena, dan tepung beras. Hasil analisis terhadap cake bengkuang dengan kombinasi perlakuan penambahan bahan pengikat dan pengurangan kadar air terlihat pada Gambar 2. Perlakuan A3B3 (penambahan tepung beras dan pengurangan kadar air dengan dipress) menghasilkan cake bengkuang dengan kadar air terendah yakni $26,97 \%$ yang diikuti oleh perlakuan A3B2 (penambahan tepung beras dan pengurangan dengan dijuicer) dengan kadar air 27,72\% dan A2B3 (penambahan tepung maizena dan pengurangan dengan dipress) kadar air $28,50 \%$. 


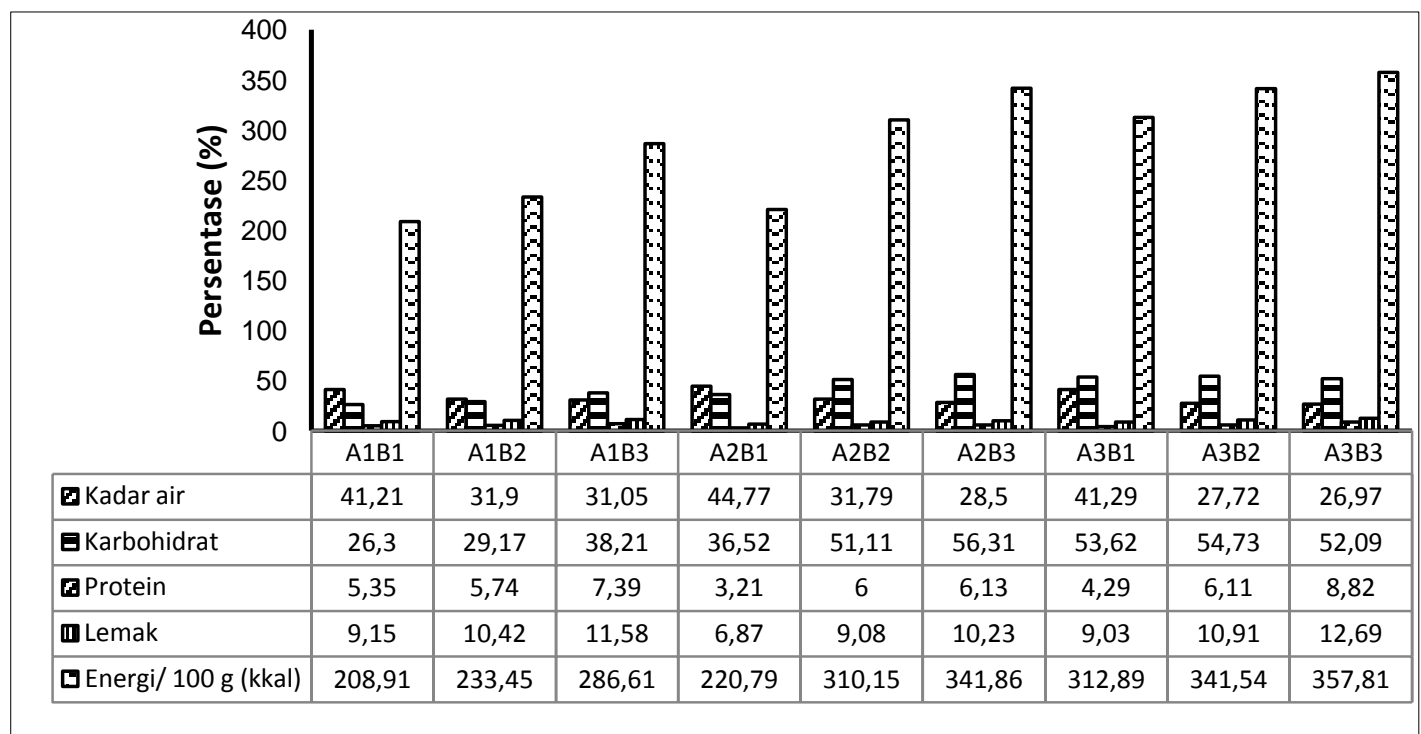

Gambar 2. Hasil analisis cake bengkuang

Bengkuang yang dipress dapat mengurangi kadar air sebanyak 3,42\% dibanding bengkuang yang hanya diblender, dan mengurangi kadar air cake sebanyak 10,16\% - 16,27\%. Tepung maizena mampu mengurangi kadar air cake bengkuang sebesar $16,27 \%$ yang lebih tinggi dibanding kelapa (10,16\%) dan tepung beras $(14,32 \%)$. Tepung maizena menurut Sholihah (2015), sering menjadi bahan tambahan dalam pembuatan cake untuk menghasilkan tekstur makanan yang lebih pas dan sempurna. Jumlah penggunaannya tidak boleh terlalu banyak biasanya $10-30 \%$ dari takaran tepung terigu sementara pada penelitian ini tepung maizena yang digunakan sekitar $17 \%$.

Yeni et al., (2013) dan Pratiwi (2015) menyatakan bahwa bengkuang dapat dibuat aneka olahan makanan sebagai subsitusi untuk mengurangi penggunaan tepung terigu. Dari kandungan airnya cake bengkuang tergolong makanan semi basah. Dengan pengurangan kadar air diharapkan cake bengkuang mempunyai daya simpan yang lebih lama.

Kandungan karbohidrat dari cake bengkuang pengaruh perlakuan penelitian ini terlihat kecenderungan kandungan karbohidrat lebih rendah pada penambahan kelapa parut. Hal ini dapat disebabkan karena karbohidrat yang berasal dari penambahan tepung maizena (A2) dan tepung beras (A3). Menurut Direktorat Gizi Departemen Kesehatan RI
(1996) karbohidrat pada tepung maizena $85 \%$, pada tepung beras $80 \%$, dan pada kelapa hanya mengandung karbohidrat $10 \%$ sedangkan kandungan protein dan lemak cake bengkuang pengaruh perlakuan penelitian ini menunjukkan nilai yang tidak jauh berbeda, sehingga dapat dinyatakan bahwa nilai kalori cake bengkuang ini lebih dipengaruhi oleh perbedaan kandungan karbohidrat. Menurut Syarief dan Irawati (1998) nilai kalori dihitung dengan menjumlahkan kalori protein 4 kalori/gram, lemak 9 kalori/gram, dan karbohidrat 4 kalori/gram.

Kandungan protein cake bengkuang berasal dari bahan penolong berupa telur, tepung, dan mentega yang digunakan. Kandungan protein cake bengkuang pengaruh perlakuan pada penelitian ini berkisar 3,21 - 8,82\%. Menurut Dedeh dan Sackey (2004) pemanasan tidak menyebabkan kehilangan protein pada produk dimana protein yang terdenaturasi oleh panas akan tetap terukur sebagai protein pada saat pengukuran.

Hasil uji organoleptik cake bengkuang seperti terlihat pada Gambar 3. Dari Gambar 3 terlihat penilaian warna, aroma, rasa, dan tekstur cake bengkuang yang memberikan nilai tertinggi adalah perlakuan A1B3 diikuti oleh A2B3.

Organoleptik merupakan pengujian terhadap bahan makanan berdasarkan kesukaan atau kemauan untuk menilai suatu produk. Dalam penilaian bahan 
pangan sifat yang menentukan diterima atau tidak suatu produk adalah sifat indrawinya. Penentu bahan makanan pada umumnya sangat ditentukan oleh beberapa faktor antara lain warna, rasa, tekstur, aroma, dan nilai gizi (Winarno et al., 2004).

Rasa merupakan faktor yang paling penting dalam menentukan keputusan bagi konsumen untuk menerima atau menolak suatu produk pangan. Meskipun parameter lain nilainya baik, jika rasa tidak enak atau tidak disukai maka produk akan ditolak. Rasa manis pada produk bengkuang disamping dari gula yang ditambahkan juga berasal dari bengkuang itu sendiri dimana menurut Lukitaningsih (2009) dan Syarif dan Waryono (2014) rasa manis berasal dari suatu oligosakarida yang disebut inulin yang tidak bisa dicerna oleh tubuh manusia dan rendah kalori, dimana sifat ini berguna bagi penderita diabetes atau orang yang berdiet rendah kalori. Manfaat lain inulin menurut Lestari (2013) yaitu sebagai prebiotik yang bermanfaat bagi kesehatan di dalam usus dengan menghambat pertumbuhan bakteri pathogen, meningkatkan kekebalan tubuh, melancarkan pencernaan, mengurangi resiko kanker usus serta mengatur konsentrasi hormon insulin dan glukagon dan selain itu dapat meningkatkan penyerapan kalsium sehingga dapat mencegah resiko osteoporosis bagi lansia serta berguna untuk pertumbuhan tulang dan gigi bagi anak-anak.

Pengamatan daya simpan cake bengkuang dilakukan pada suhu kamar $\left(27-30^{\circ} \mathrm{C}\right)$ dan pada showcase suhu $15^{\circ} \mathrm{C}$. Hasil pengamatan daya simpan cake bengkuang pada suhu kamar berkisar 3 sampai 5 hari sedangkan pada suhu kulkas berkisar 2 minggu hari sampai 1 bulan. Perlakuan yang memberikan daya simpan lebih lama (5 hari) hanya perlakuan A2B3 (penambahan tepung maizena dan pengurangan kadar air bengkuang dengan dipress). Menurut Fardiaz (1989) daya tahan bahan ikut ditentukan oleh kandungan air dalam bahan makanan, batas kadar air mikroba tidak dapat tumbuh adalah $14-15 \%$.

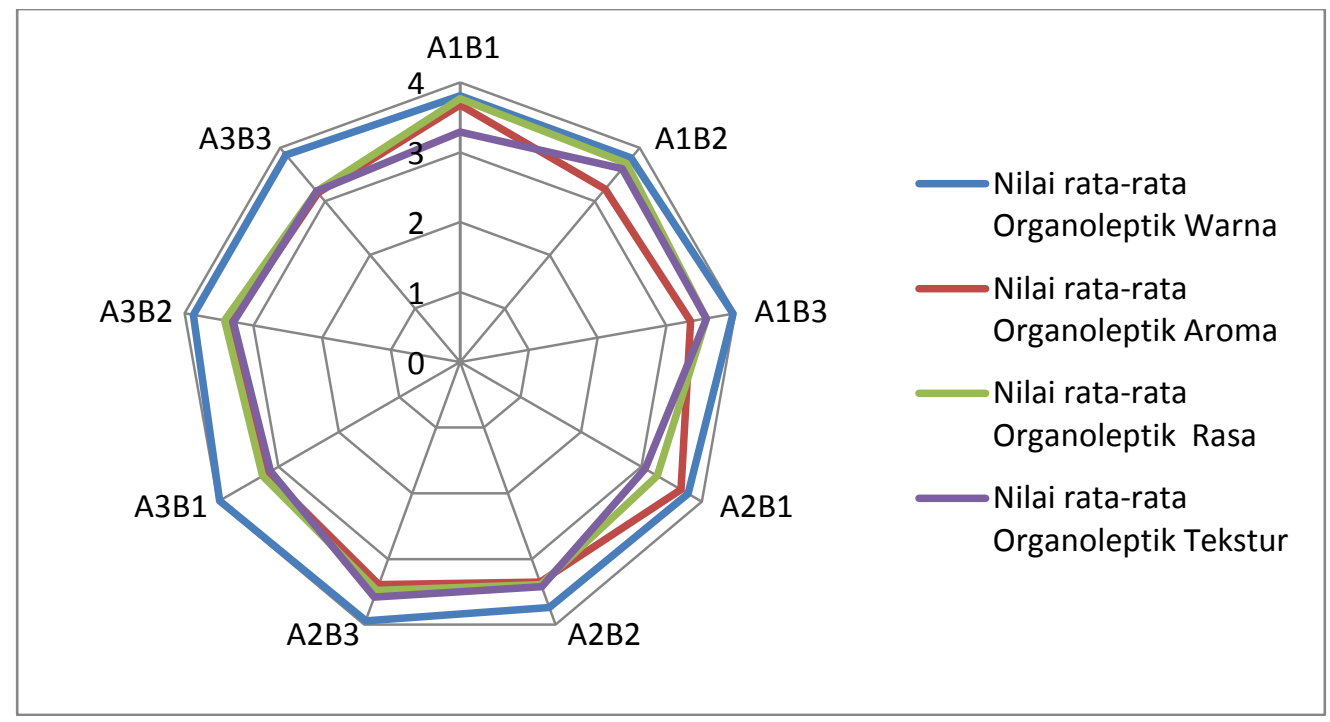

Gambar 3. Hasil uji organoleptik cake bengkuang

Umur simpan atau waktu kadaluarsa merupakan suatu rentang waktu yang menyatakan bahwa produk masih dalam keadaan aman dikonsumsi, tetap memenuhi sifat sensoris, kimia, fisik dan mikrobiologis sesuai dengan penyataan nilai gizi yang tercantum dalam label (Supriyadi, 2009).

Berdasarkan analisis dan pengamatan dapat dinyatakan bahwa perlakuan penambahan tepung maizena dan pengurangan kadar air bengkuang dengan dipress (A2B3) memberikan hasil optimal baik terhadap analisis kimia, nilai organoleptik maupun daya simpannya.

Bengkuang segar juga mengandung serat pangan, kalsium dan inulin yang baik untuk kesehatan. Hasil analisis kandungan serat pangan, kalsium, inulin, dan vitamin B1 pada bengkuang segar dan pada cake 
bengkuang yang memberikan hasil optimal pada penelitian ini seperti terlihat pada Tabel 2.

Dari data Tabel 2 terlihat bahwa serat pangan pada bengkuang segar dan cake bengkuang ini cukup tinggi dimana menurut Chooi (2008) bengkuang mengandung serat $0,5-1 \%$. Sementara bengkuang segar yang digunakan pada penelitian ini mengandung serat $5,49 \%$ dan pada cake bengkuang mengandung serat $5,98 \%$. Hal ini yang membedakan cake bengkuang dengan cake biasa serta mengandung kalsium dan inulin yang semakin tinggi persentase kandungannya pada olahan berupa cake dibanding dengan bengkuang segar. Menurut Aisyah et al., (2014) pemasakan dengan melibatkan panas merupakan salah satu proses pengolahan yang banyak dilakukan skala rumah tangga atau skala industri. Pilar et al., (2011) dalam Aisyah et al., (2014) menyatakan bahwa pemanasan dapat berpengaruh negatif terhadap parameter mutu tetapi dalam beberapa percobaan perlakuan pemanasan meningkatkan mutu dan memberikan hasil yang lebih menarik bergantung pada jenis sayuran atau buah dan jenis pemasakannya.

Kandungan vitamin B1 pada bengkuang segar dan cake bengkuang tidak terdeteksi dimana limit deteksi yakni 0,52 ppm. Jadi dapat dinyatakan bahwa kandungan vitamin B1 pada bengkuang ini sangat rendah sekali.

Tabel 2. Hasil analisis bengkuang segar dan cake bengkuang

\begin{tabular}{lcc}
\hline \multirow{2}{*}{ Parameter } & \multicolumn{2}{c}{ Kandungan pada } \\
\cline { 2 - 3 } & $\begin{array}{c}\text { Bengkuang } \\
\text { segar }\end{array}$ & $\begin{array}{c}\text { Cake } \\
\text { bengkuang } \\
\text { (A2B3) }\end{array}$ \\
\hline $\begin{array}{l}\text { Serat } \\
\text { pangan }\end{array}$ & $5,49 \%$ & $5,98 \%$ \\
\hline Vitamin B1 & Not detected & Not detected \\
\hline Kalsium & $\begin{array}{c}13,20 \mathrm{mg} / \\
100 \mathrm{~g} \\
(132 \mathrm{ppm})\end{array}$ & $\begin{array}{c}27,77 \mathrm{mg} / \\
100 \mathrm{~g} \\
(277,7 \mathrm{ppm})\end{array}$ \\
\hline Inulin & $4,23 \%$ & $5,92 \%$ \\
\hline
\end{tabular}

Menurut Direktorat Gizi Departemen Kesehatan (1996), bengkuang mengandung vitamin B1 sebesar 0,04 $\mathrm{mg} / 100 \mathrm{~g}$ dan vitamin $\mathrm{C}$ juga cukup tinggi pada bengkuang $20 \mathrm{mg} / 100 \mathrm{~g}$, sesuai d

engan hasil penelitian Hermianti et al., (2013) pada cake bengkuang juga mengandung vitamin $\mathrm{C}$ sebanyak 0,03\% (30 mg/100g). Menurut de Melo et al., (1994) ampas bengkuang kaya akan serat pangan dan berpotensi sebagai sumber prebiotik karena masih mengandung inulin dan oligosakarida lainnya. Ditambahkan oleh Hariati et al., (2012) umbi bengkuang mengandung inulin yang tidak dapat dicerna sehingga dapat digunakan sebagai pengganti gula. Kandungan inulin pada bengkuang memiliki peran prebiotik dalam usus artinya dapat membantu pertumbuhan bakteri baik sehingga kesehatan usus tetap terjaga. Inulin juga berguna bagi kesehatan tulang dengan cara membantu meningkatkan penyerapan kalsium dari makanan lain serta melindungi tulang dari osteoporosis (Naja, 2014).

Data pada Tabel 2 menunjukkan bahwa dengan pengolahan menjadi cake bengkuang kandungan vitamin $\mathrm{C}$, kalsium, inulin dan serat pangan tidak hilang dengan pengolahan. Dengan mengkonsumsi cake bengkuang kandungan gizi tersebut tetap dapat kita peroleh.

Manfaat yang kita peroleh dengan serat makanan adalah membantu memperlancar saluran pencernaan dan dapat mencegah dari beberapa masalah pencernaan seperti sembelit atau susah buang air besar dan kanker kolon (Bakulatz, 2011). Vitamin C sangat baik untuk meningkatkan sistem kekebalan tubuh dan menjauhkan dari berbagai jenis penyakit, selain itu vitamin $\mathrm{C}$ juga merupakan sumber antioksidan alami yang dapat membantu tubuh dalam mencegah radikal bebas (Ngenee, 2012). Kandungan vitamin $\mathrm{C}$ pada bengkuang yang bertindak sebagai antioksidan dapat membantu mempercepat proses penyembuhan penderita sariawan, disamping itu juga dapat membantu menurunkan kadar kolesterol dalam darah (Bakulatz, 2011). Kalsium yang terkandung dalam buah bengkuang adalah zat yang sangat bagus bagi tubuh terutama untuk ginjal dan empedu. Inulin sangat baik untuk penderita diabetes atau orang yang berdiet rendah kalori (Heyne, 1987). 


\section{KESIMPULAN}

Perlakuan pengurangan kadar air bahan baku bengkuang dan penambahan bahan pengikat kadar air dapat meningkatkan mutu cake bengkuang. Perlakuan pengurangan kadar air bengkuang dengan dipress dapat mengurangi kadar air bengkuang lebih banyak dibanding pengurangan dengan dijuicer. Bengkuang yang dipress dapat mengurangi kadar air bahan baku sebanyak 3,42\%, dan mengurangi kadar air cake sebanyak 10,16\%-16,27\% tergantung bahan pengikat kadar air. Tepung maizena mampu mengurangi kadar air pada cake bengkuang sebesar $16,27 \%$ yang lebih tinggi dibanding kelapa $(10,16 \%)$ dan tepung beras $(14,32 \%)$.

Penelitian yang memberikan hasil optimal terhadap mutu cake bengkuang adalah perlakuan (A2B3) yakni perlakuan penambahan tepung maizena dan pengurangan kadar air bahan baku bengkuang dengan dipress. Perlakuan (A2B3) tersebut dengan kadar air $28,50 \%$, karbohidrat $56,31 \%$, protein $6,13 \%$, lemak $10,23 \%$, energi $341,86 \% \mathrm{kkal} / 100 \mathrm{~g}$, serat makanan 5,98\%, kalsium 27,77 mg/100 g dan inulin 5,92\% dengan daya simpan yang meningkat menjadi 5 hari pada suhu kamar sedangkan pada suhu kulkas $\left(15^{\circ} \mathrm{C}\right)$ tahan sampai 1 bulan dimana setelah waktu tersebut tekstur cake mulai menjadi keras.

\section{UCAPAN TERIMA KASIH}

Penulis menyampaikan terima kasih pada Marlusi atas bantuan dan kerjasamanya pada penelitian ini.

\section{DAFTAR PUSTAKA}

Aisyah, Yuliani., Rasdiansyah, dan Muhaimin. 2014. Pengaruh pemanasan terhadap aktivitas antioksidan pada beberapa jenis sayuran. Jurnal Teknologi dan Industri Pertanian. 6(2). 2014. Universitas Syiah Kuala. Banda Aceh.

Bakulatz. 2011. http://bakulattz.wordpress. com. Manfaat buah bengkuang.
Braker, Flo. 2003. The simple art of perfect baking. Chronicle Books. ISBN 0-81184109-X.

Chooi, O.H. 2008. Vegetables for health and healing. Utusan Publicaions \& Distributors Sdn Bhd. Kuala Lumpur.

Dewi, N.S., Parnanto, N.H.R., Ridwan A. 2012. Karakteristik sifat fisikokimia tepung bengkuang (Pachyrhizus erosus) dimodifikasi secara asetilasi dengan variasi konsentrasi asam asetat selama perendaman. Jurnal Teknologi Hasil Pertanian. V (2). Agustus 2014. Universitas Sebelas Maret. Surakarta.

Dedeh, S.S. dan Sackey, A. 2004. Chemical composition and the effect of processing an oxalate content of cocoyam xanthosoma sagittifolium and Colocasia esculenta $L$. Journal of Food Chemistry 85.

Direktorat Gizi Departemen Kesehatan RI. 1996. Daftar komposisi bahan makanan. Bhratara Karya Aksara. Jakarta.

Dinas Pertanian Kota Padang. 2013. Rekapitulasi jumlah tanam, panen, produksi tanaman sayuran buah semusim di kecamatan Kota Padang. Dinas Pertanian, Peternakan, Perkebunan dan Kehutanan Kota Padang.

De Melo, EP., N. Krieger, and T.L.M. Stamford. 1994. Physchochemical properties of Jacatupe (Pachyrhizus erosus L. Urban) starch. Starch 46.

Fardiaz, S. 1989. Mikrobiologi pangan. IPB Press. Bogor.

Hariati, Isni, B.T., Chairun, N., dan Barus, A. 2012. Tanggap pertumbuhan dan produksi bengkuang terhadap beberapa dosis pupuk kalium dan jarak tanam. Jurnal online Agroekoteknologi.

Harmayanti, E. 2011. Potensi serat bengkuang (sebagai prebiotic pada Bifidobacterium lognum dan Lactobacillus A. Seminar nasional PATPI. 
Haryadi. 1993. Dasar-dasar dan pemanfaatan ilmu dan teknologi pati. Agritech.Yogyakarta.

Hermianti, W., Firdausni, Marlusi, dan Wahyuningsih, T. 2013. Penelitian pemanfaatan bengkuang menjadi pangan semi basah. Komunikasi No. 312. Baristand Industri Padang.

Heyne, K. 1987. Tumbuhan berguna Indonesia jilid 2. Yayasan Sarana Wanajaya. Jakarta.

Kurniawan, S. 2013. Daun kemangi, bawang merah, bawang putih dan bengkuang terapi herbal kesehatan dan kecantikan. Diva Press.

Lestari, P.I. 2013. Pengembangan dan validasi metode KLT densitometry untuk penetapan kadar inulin dalam ekstrak air umbi bengkuang (Pachyrhizus erosus L.) Fakultas Farmasi Universitas Jember.

Lukitaningsih, E. 2009. The exploration of whitening and sun screening compounds in bengkoang roots (Pachyrhizus erosus). Deutschen Akademischen Austauschdienstes) Wurzburg.

Naja, A. 2014. Manfaat jus bengkuang untuk kesehatan yang luar biasa.

Ngenee, I. 2012. Manfaat bengkuang bagi kesehatan.

Pratiwi, N.U. 2015. Pengaruh substitusi tepung bengkuang terhadap kualitas brownies kukus. Program Studi Pendidikan Kesejahteraan Keluarga
Fakultas Teknik Universitas Negeri Padang.

Setyaningsih, D., Apriyantono, A., Sari, M.P. 2010. Analisis sensori untuk industri pangan dan agro. IPB, Bogor.

Sholihah, N.S. 2015. Maizena. Kerjanya.net.

Supriyadi. 2009. Pangan kadaluarsa, siapa yang bertanggung jawab. Foodreview IV (11). PT. Media Pangan Indonesia. Bogor.

Susilo, D.U.M dan Imelda, F. 2007. Pembuatan cake kacang tunggak (Vigna unguiculata) dengan pencampuran tepung gandum. Politeknik Negeri Pontianak.

Syarief, R., dan Irawati A. 1998. Pengetahuan bahan untuk industri pertanian. PT. Mediyatama Sarana Perkasa. Jakarta.

Syarif, W., dan Waryono. 2014. Pelatihan kewirausahaan pengolahan bengkuang sebagai upaya peningkatan keterampilan dan ekonomi keluarga. Prosiding Konsensi Nasional Asosiasi Pendidikan Teknologi dan Kejuruan (APTEKINDO) ke 7. FPTK Universitas Pendidikan Indonesia Bandung.

Winarno, F.G., Fardiaz, S. dan Fardias, D. 2004. Pengantar teknologi pangan. Gramedia. Jakarta.

Yeni, G., Failisnur, dan Firdausni. 2013. Membuat aneka olahan bengkuang. IPB Press. Bogor. 